\title{
Hydro-Diplomacy in Southeast Asia: The Taiwanese Case
}

\author{
Filippo Verre \\ University of Pisa
}

International isolation is the main concern of Taiwan's foreign politics. The proximity with mainland China urged Taiwan to rely on several different strategies to maintain the coveted geopolitical survival from Beijing's sovereignty claims. Recently, among the various strategies adopted across the years, Taipei has used hydro-diplomacy to expand its presence in Southeast Asia. The main sponsor of such peculiar form of diplomacy has been President Tsai Ing-wen, in charge since May 2016. In January 2019, her inclusive policies towards ASEAN nations, particularly towards Indonesia, led to the signing of a historic agreement for the construction of a water purification plant in East Java.

Keywords: hydro-diplomacy, hydro-geopolitics, international relations, Taiwan, China

\section{INTRODUCTION}

In the last years, the role of water in international relations has grown exponentially. Such a situation is due to the extreme relevance of water, the so called "blue oil", not only for basic human needs but also in terms of the production and consumption of clean energy. Because of that, nowadays hydro resources are often used by the governments to implement foreign policies or to mold diplomatic strategies. On this respect, recently Taiwan has relied on hydro-diplomacy in order to expand its geopolitical presence in Southeast Asia. A major part in this peculiar diplomacy has been played by the Taiwan Water Corporation (TWC), a state-owned company operating since 1974. For the most part of its history TWC served as water utility providing filters, clean hydro resources and technical expertise in Taiwan and offshore islands. However, since 2019 Taipei's water corporation has become a valuable tool for the Taiwanese diplomacy. After signing a Memorandum of Understanding (MOU) with the Indonesian government, Taiwan is expected to build a water purification plant in East Java, one of Indonesia's most populated provinces (Anwar, 2020; 115-117). TWC and six private water treatment firms will contribute with operative knowledge and technology in the realization of this infrastructure.

The long lasting confrontation with mainland China forced Taiwan to sharpen the weapons of its diplomacy in various regards. Across the years, Taipei has put in place several strategies aimed at preserving its international space intact from Beijing's sovereignty claims. Hitherto, "economic diplomacy" and "technological diplomacy" have been the preferred blueprints in this quest. Nevertheless, the most recent strategy of the Taiwanese foreign politics has been intertwined with hydro-geopolitics. The emergence of this phenomenon has evoked several inquiries related to the role played by Taiwan in Southeast Asia. What are the relations between Taipei and the ASEAN countries? Is hydro-diplomacy an effective tool to increase Taiwanese status in the region? Will the MOU signed in 2019 affect positively the relations between Taiwan and Indonesia? 
This article attempts to provide answers to the above questions. Primarily, it focuses on the measures adopted by Taiwan in order to preserve its sphere of influence in the region. Since late 1980s, a number of leaders have tried to progressively distance the island's economic and political destiny from China. Tsai Ing-wen, the current leader in charge, has inaugurated a new political strategy in this regard: the "New Southbound Policy". Hydro-diplomacy is essential in this project. Subsequently, the article will discuss the relations between Taiwan and Indonesia. The close bond between these two regional powers has contributed positively for the finalization of the agreement. Finally, a discussion over the MOU signed in 2019 will be presented. In this final section, two aspects will be examined: the Indonesian need for clean water, especially concerning East Java, and the operative efficiency of TWC. These two elements combined represent the milestones regarding the achievability of Taiwanese hydro-diplomacy in Indonesia.

\section{GEOPOLITICAL FRAMEWORK}

\section{Taiwan's Diplomatic Mission: Avoiding International Isolation}

Nowadays, Taiwan is a vibrant and prosperous entity with an established democratic system. It has one of the most dynamic economic apparatuses of Southeast Asia as well as a relevant technological know-how in various sectors. However, as mentioned, the proximity with mainland China poses great risks for the island's geopolitical survival. Indeed, international isolation is the main concern of both past and recent Taiwanese leaders. In order to limit such isolation that could potentially jeopardize its institutional future, Taiwan has entrusted its foreign diplomacy to the so called "Go South Policy" (GSP) (Bing, 2017: 97-98). The latter refers to actions aimed at strengthening relations between Taipei and the countries "south" of Taiwan, especially in Southeast Asia (Bing, 2017; Didier, 2018). The first president who theorized this strategy was Lee Teng-hui (1988-2000). Before Lee took office, the previous leaders, Chiang Kai-shek (1949-1975) and his son Chiang Ching-kuo (1975-1988), had strictly adhered to the "One China" principle. According to it, the Republic of China (Taiwan) had to break off diplomatic relations with any country that established official ties with Beijing (the People's Republic of China) (Didier, 2018; Chen, 2002). As a consequence of this uncompromising strategy, numerous nations rapidly ceased diplomatic connections with Taiwan, especially following the island's exclusion from international organizations which required statehood as a precondition for membership (Bing, 2017: 100-101).

\section{Lee Teng-hui (1988-2000)}

The inexorable contraction of Taiwan's international space due to the emergence of China as a regional power forced Lee Teng-hui to dramatically change diplomatic strategy. He soon realized that Taipei needed to construct a credible image, alternative to mainland China, in order to seek for regional space. Once he came to power, he announced that his administration would pursue what he called "pragmatic diplomacy", whose main goal was to boost Taiwan's visibility region wide (Hickey, 2006).

In late 1980s, a major concern for Taipei's rulers was that the economic system of the island, which was progressively emerging, was becoming too much dependent from Beijing's apparatus (Marston \& Bush 2018; Bing, 2017). According to Lee, Taipei was too enmeshed with Chinese market and industries; the president of the Republic of China was not in favor of greater economic exchanges between China and Taiwan, since he believed in the long term Beijing would inexorably engulf Taiwan's dynamic but small economic system. Because of that, Lee encouraged a financial diversification as well as a resolute opening to other Asia's markets (Bing, 2017). Following the economic expansion occurred in early 1990s, Taiwan's absolute investments in both China and Southeast Asia increased. However, despite the intentions, during the first years of Lee's mandate Taipei was not able to break entirely away from Chinese economy. As evidence of this, Taiwanese investment in China outpaced investment in Southeast Asia (Chen, 2002).

In October 1993, Taiwan's Ministry of Economic Affairs formulated the "Guidelines on Strengthening Economic Work" in Southeast Asian region as a reaction to Taipei's excessive dependence on the Chinese economy. The guidelines were the prodromes of the "Go South" policies taken place in the following administrations. According to Lee's view, the government was supposed to support Taiwanese companies relocate manufacturing plants from China to Southeast Asia, implement employment opportunities in the 
host countries, integrate the latter in Taiwan's apparatus, consolidate Taipei's industrial system in the ASEAN free trade area and promote Taiwan's status within the regional security framework (Bing, 2017: 102). In this phase, great attention was dedicated in signing agreements with the more developed maritime members of ASEAN, namely the Philippines, Singapore, Malaysia, Thailand and Indonesia (Marston \& Bush 2018; Hickey, 2006). Concretely, major investment projects included the Subic Bay Industrial Park in the Philippines (1994) and the Medan Industrial Park in Indonesia (1994-1996) (Bing, 2017:103). This strategy had a dual purpose. Besides diversifying the economic activities, Lee aimed at gaining a political result. In fact, in upgrading relations with ASEAN members, the leader hoped to forge bilateral ties between Taiwan and Southeast Asian countries that would lead towards a political rapprochement as well (Hickey, 2006). Therefore, the "pragmatic diplomacy" proposed by Lee Teng-hui laid the foundation for Taipei's partial recognition in the region as a separate entity from the People's Republic of China. By the end of 1996, this approach paid dividends, since Taipei's investments towards Southeast Asia (US \$12.74 billion) outscored mainland China (US \$ 9.83 billion) (Marston \& Bush 2018; Hickey, 2006). As pointed out by Bing $(2017,103)$ the official bilateral economic agreements signed in 1994-1996 exceeded the number of bilateral economic agreements signed between Taiwan and Southeast Asian countries in the previous twenty years.

Beijing was not particularly enthusiastic of the independent political strategy exercised by Taiwan. The latter was considered as a rebel appendix by mainland China and still nowadays the communist regime aims to reinsert the island within its institutional framework. In addition, the outflow of Taiwanese investments from Chinese markets caused significant economic hardship for many industries operating in partnership with Taipei's companies. Lee's "pragmatic diplomacy" took place also in late 1990s, when the president launched a second GSP (Rawnsley, 2012). In May 1997, following the onset of the 1997-98 Asian Financial Crisis (AFC), Taiwan copiously invested in the region withdrawing billions of US \$ from the Chinese market to redirect in Southeast Asian economies. The AFC hit Malaysia, Thailand, the Philippines and Indonesia very hard, while Taiwan and China escaped relatively unscathed (Rawnsley, 2012; Hickey, 2006). Because of that, Taipei felt that the financial crisis presented an important opportunity for Taiwanese business to expand its presence and affairs in Southeast Asia. Consequently, in January 1998 Taiwanese Premier Vincent Siew held an official trip in the Philippines and Indonesia (where he met with Jakarta's president Suharto) and proclaimed Taiwan's intention to support and reinvigorate the local economies severely hit by the crisis.

Notwithstanding the "pragmatic diplomacy" sponsored by Lee's administration, it ought to be pointed out that many Taiwanese enterprises were unenthusiastic about "going out" to Southeast Asia and leave the Chinese "comfort zone". This was mostly due to the economic, social and political instabilities of the countries affected by the crisis in comparison with China's relatively stable situation following the AFC (Marston \& Bush 2018; Hickey, 2006). Moreover, the common socio-cultural environment between Taiwan and China was a further element of closeness that propelled Taipei's firms to keep their presence in mainland China rather than relocating in other unsure Asian areas (Hickey, 2006). As evidence of that, during the last years of Lee's presidency the flow of Taiwanese investments into Beijing's economy increased, despite the second GSP launched in the aftermath of 1997 (Rawnsley, 2012). By 1999-2000, Taiwanese investment in the Philippines, Indonesia, Singapore and Vietnam stagnated, while mainland China experienced a renovation of Foreign Direct Investment (FDI) coming from Taipei's enterprises (Bing, 2017).

\section{Chen Shui-bian (2000-2008)}

In 2000, Chen Shui-bian (2000-2008) replaced Lee Teng-hui as president of Taiwan. Chen was the first Taiwanese leader not enrolled in the Kuomintang, since he was a member of the Democratic Progressive Party (DPP). However, from a teleological standpoint the new leader in charge followed the path inaugurated by Lee's administration (Hickey, 2006). Chen did not disagree with the rationale underpinning of the "pragmatic diplomacy", rather he aimed at taking the struggle against China a step forward. Concretely, the new leader felt that despite the good premises, Lee's foreign policy had not gone far enough (Marston \& Bush 2018; Hickey, 2006). In this regard, Chen wanted the symbolic, if not formal, recognition 
of Taiwan's sovereignty in the region, or at least the dignity and identity of Taiwan as a political entity separate from China. President Chen began his presidency in 2000, and the immediate focus of his foreign policy was intensifying diplomatic relations with the United States and Japan, two of the fiercest geopolitical rivals of Beijing. This aggressive political attitude was epitomized by the so called "offensive diplomacy". The latter was the symbol of Chen's presidency in contraposition with the previous "pragmatic diplomacy" sponsored by Lee Teng-hui (Bing, 2017).

Symbolism took a central role in Chen's vision. His visits to countries Taiwan did not have diplomatic relations with, as well as his claims in being received in a way suggesting that Taiwan was a sovereign political entity, were important in this regard (Rawnsley, 2012; Hickey, 2006). Furthermore, he wanted to secure membership of international organizations that required statehood as a prerequisite including the United Nations (UN). Chen was a solid advocator of tactical distancing from mainland China, which he considered a dangerous threat either politically and economically for Taiwan's long term interests. On this respect, in late July 2002 in a meeting with the Asia Taiwanese Chambers of Commerce Chen declared: "We cannot have too high an expectation of China, especially in economics and trade. (...) The market in mainland China is neither the sole, nor the safest, nor the final external market of Taiwan, [and hence] we must emphasize investment in Southeast Asia" (Bing, 2017; 106). The GSP launched under Chen's term was focused on the six more developed ASEAN economies, namely Singapore, Malaysia, Thailand, Indonesia, the Philippines and Vietnam (Rawnsley, 2012; Hickey, 2006). The economic initiatives proposed in this phase included promises of relevant Taiwanese FDI in ASEAN countries, promotion of agricultural-technical assistance (especially in Indonesia), negotiations for the importation of migrant labour into Taiwan and the attempt to sign Free Trade Agreements (FTA) with selected Southeast Asian countries (Marston \& Bush 2018; Bing, 2017).

Chen's "offensive diplomacy" was urged by a historic event: China's admission into the World Trade Organization (WTO) in 2000. Furthermore, in November of the same year Beijing managed to negotiate an agreement with the ASEAN countries according to which a number of FTA were to be signed in the following years between China and ASEAN members (Bing, 2017: 109). These events encouraged Taipei to accelerate on its GSP. However, as shown in Table 1, the results were not entirely satisfactory.

TABLE 1

TAIWANESE INVESTMENT IN CHINA AND SOUTHEAST ASIA, 2001-2008

\begin{tabular}{ccc}
\hline Year & $\begin{array}{c}\text { Taiwanese Investment in China } \\
\text { (US \$ millions) }\end{array}$ & $\begin{array}{c}\text { Taiwanese Investment in Southeast } \\
\text { Asia (US \$ millions) }\end{array}$ \\
\hline 2001 & $\$ 2.884,15$ & $\$ 2.954,99$ \\
2002 & $\$ 6.723,06$ & $\$ 1.057,74$ \\
2003 & $\$ 7.698,78$ & $\$ 1.415,54$ \\
2004 & $\$ 6.940,66$ & $\$ 1.981,26$ \\
2005 & $\$ 6.006,95$ & $\$ 1.611,46$ \\
2006 & $\$ 7.642,34$ & $\$ 2.132,36$ \\
2007 & $\$ 9.970,55$ & $\$ 4.030,64$ \\
2008 & $\$ 10.691,39$ & $\$ 12.488,00$ \\
\hline
\end{tabular}

Sources: Department of Investment Service, Taiwan's Ministry of Economic Affairs, Cross-Strait Economic Statistic Monthly (Republic of China: Mainland Affairs Council, 2001-2008).

Despite the proclaims, Taiwan's investment flows in China outweighed regularly the investments in Southeast Asia with the only exceptions of 2001 and 2008. If we do not take into consideration these two years, namely when Taipei's FDI towards Southeast Asia was slightly more consistent than mainland China, the preferred destination of Taiwanese expenditure was by far Beijing's market. As occurred under Lee's leadership, often Taiwanese investors changed their mind after initially adhering to Taipei's doctrine (Rawnsley, 2012; Hickey, 2006). It should be highlighted that also during Chen's presidency the majority of Taiwan's entrepreneurs, despite "answering the call" from the government to move from China to 
Southeast Asia, later decided to move back to China due to the better investment environment and cultural proximity (Bing, 2017: 109-110).

\section{Ma Ying-jeou (2008-2016)}

In 2008 the Kuomintang took back power in Taiwan with the presidency of Ma Ying-jeou, who remained in charge until 2016. Unlike his two predecessors, president Ma had a softer approach with China, since he believed that a harsh confrontational strategy towards Beijing was bound to harm Taipei's geopolitical and economic status in Southeast Asia (Bing, 2017: 110). Ma's foreign policy was premised on pragmatism and flexibility; during his term he did not launch a GSP's campaign and never posed great emphasis on the symbolic political recognition of Taiwan's sovereignty (Rawnsley, 2012). Such different strategy was carried out through the so called "viable diplomacy". The latter had nothing in common with Chen's "offensive diplomacy", due to its long term impracticability in relation with the Chinese superpower (Didier, 2018: 233-235). On the other hand, Ma's vision actually shared many characteristics of Lee's "pragmatic diplomacy", especially concerning the expansion of Taipei's financial presence in Southeast Asia as well as the economic diversification of Taiwanese companies in other regional markets (Lin, 2008). However, a key difference between $\mathrm{Ma}$ and Lee was related to the teleological aspect of their diplomatic approaches. While the "pragmatic diplomacy" had a confrontational relationship with China, Ma's "viable diplomacy" was premised on an institutional truce with Beijing (Marston \& Bush, 2018; Bing, 2017).

Similarly to Chen, Ma Ying-jeou sought to obtain substantive relations between Taiwan and countries with which it did not have formal diplomatic relations with. Nevertheless, according to Ma's vision Taiwan had nothing to gain in achieving political and symbolic benefits associated with being a sovereign state (Rawnsley, 2012). In addition, as pointed out by the new leader, it was better for Taipei refraining from competing with China in winning over diplomatic disputes. Essentially, Taiwan's main goal needed to be seeking ways to join international forums without insisting on having the formalities of a sovereign state to join those platforms (Marston \& Bush, 2018; Bing, 2017). It ought to be mentioned that Ma's detractors labelled his "viable diplomacy" as "surrender diplomacy", due to his prone approach towards mainland China (Bing, 2017: 110). During his tenure, Taiwan signed more than twenty economic and technical agreements with Beijing, the most important of which was the Economic Cooper Framework Agreement (ECFA). The latter, essentially a FTA, reassured the Taiwanese economic elite that China's market was still central for Taipei's foreign financial policy (Rawnsley, 2012). Unlike what occurred under Lee's and Chen's terms, when several Taiwanese companies after initially adhering to GSP, relocated in mainland China, Ma aimed at using the ECFA to establish a positive and durable relation with Beijing (Marston \& Bush, 2018; Bing, 2017). This approach, however, was not detrimental to Taiwanese financial expansion in Southeast Asia. As evidenced in Table 2, Taipei during Ma's presidency kept its FDI's rate in the region constant without even proclaiming a GSP.

TABLE 2

TAIWANESE INVESTMENT IN CHINA AND SOUTHEAST ASIA, 2009-2015

\begin{tabular}{ccc}
\hline Year & $\begin{array}{c}\text { Taiwanese Investment in China } \\
\text { (US \$ millions) }\end{array}$ & $\begin{array}{c}\text { Taiwanese Investment in Southeast } \\
\text { Asia (US \$ millions) }\end{array}$ \\
\hline 2009 & $\$ 7.140,00$ & $\$ 2.096,61$ \\
2010 & $\$ 14.620,00$ & $\$ 2.394,58$ \\
2011 & $\$ 14.380,00$ & $\$ 2.279,54$ \\
2012 & $\$ 12.790,00$ & $\$ 5.852,44$ \\
2013 & $\$ 9.190,00$ & $\$ 1.467,43$ \\
2014 & $\$ 12.080,00$ & $\$ 2.651,43$ \\
2015 & $\$ 10.970,00$ & $\$ 2.051,24$ \\
\hline
\end{tabular}

Sources: Department of Investment Service, Taiwan's Ministry of Economic Affairs, Cross-Strait Economic Statistic Monthly (Republic of China: Mainland Affairs Council, 2008-2015). 
Clearly, the investment flows towards China exceeded by far the expenditure directed towards ASEAN countries. Nevertheless, Taipei's financial investments in Southeast Asia did not stagnate. As claimed by Bing (2017:112), on average the annual size of Taiwanese investment in Southeast Asia under Ma's leadership was still greater than it had been during Chen's administration, despite the absence of an official "Go South Policy". In addition, Ma stimulated cultural exchanges between Taiwan and other south eastern Asian nations such as the Philippines, Indonesia and Singapore (Marston \& Bush, 2018). Under his tenure, foreign students in Taiwan steadily increased. As evidence of this, in 2008, the year Ma assumed office, the total number of ASEAN students in Taiwan was 11.959. In 2015, that number had risen to 26.756 (Bing, 2017:112). In doing so, Ma increased Taiwan's status in the region not only concerning economic and financial parameters but also on a cultural basis. Therefore, unlike his two predecessors who focused mainly in boosting Taiwanese economic presence in the area and in seeking political recognition, Ma Ying-jeou was responsible of a significative bend in terms of young talent acquisitions from other Asian universities.

\section{Tsai Ing-wen's Leadership: The New Southbound Policy (NSP)}

In May 2016, another member of the DPP became head of the Taiwanese state: Tsai Ing-wen, the first woman leader in the political history of the Asian island. As soon as she took power, Tsai established herself as the champion of Taiwanese geopolitical and economic autonomy from Beijing's sovereign claims. In this regard, Tsai's government introduced the concept of "steadfast diplomacy" (Bing, 2017; Glaser, Kennedy \& Funaiole, 2018). As a consequence, Taiwan's relations with China have cooled considerably thereafter, especially due to the DPP's pro-independence leanings and to Tsai's decline to recognize the "1992 Consensus". Following the path inaugurated by Chen, during her inaugural address the new president pledged to maintain the status quo of cross-Strait relations and to strengthen ties with the United States and Japan (Glaser, Kennedy \& Funaiole, 2018; Bing, 2017). In the same occasion, she asserted that the primary goal of the DPP's led Taiwan was to "bid farewell to our past over reliance on a single market", namely on mainland China (Marston \& Bush, 2018).

\section{TABLE 3 \\ TAIWANESE DIPLOMATIC STRATEGY WITH CHINA AND SOUTHEAST ASIA SINCE LATE 1980S}

\begin{tabular}{ccccc}
\hline President & Years & Diplomatic Strategy & $\underline{\text { Attitude towards }}$ & Attitude towards \\
\hline Lee Teng-hui & $1988-2000$ & "Pragmatic Diplomacy" & Confrontational & Southeast Asia \\
Chen Shui-bian & $2000-2008$ & "Offensive Diplomacy" & Apen \\
Ma Ying-jeou & $2008-2016$ & "Viable Diplomacy" & Pragmatic, flexible & Open, friendly \\
Tsai Ing-wen & $2016-$-in place & "Steadfast Diplomacy" & Open \\
Confrontational & Open, inclusive \\
\hline
\end{tabular}

In order to achieve such bold foreign strategy, Tsai Ing-wen launched the "New Southbound Policy" (NSP). Basically, the latter did not differ much from the previous GSP initiated by Lee Teng-hui and Chen Shui-bian. The main goal remained to establish profitable and durable relations with ASEAN members and increase ties with other nations such as India, Australia and New Zealand (Glaser, Kennedy \& Funaiole, 2018). However, under Tsai's leadership the Taiwanese "Go South" policies took a step further in terms of structural organization and long term goals. As President Tsai defined it in a speech held in October 2017, "the New Southbound Policy is our new 'Regional Strategy for Asia.' Under this policy, we intend to work with countries in the region and around the world to deepen and broaden our presence in South and Southeast Asia" (Marston \& Bush, 2018). The NSP had four major tasks to be achieved between Taipei and Southeast Asian nations: the promotion of economic collaboration, talent exchange, the share of resources and the formation of solid regional links. Among these goals, hydro-diplomacy plays a central role concerning the third task, as the exchange of resources includes not only financial flows or economic investments but also the construction of infrastructures necessary for social and human development (Glaser, Kennedy \& Funaiole, 2018; Marston \& Bush, 2018). 


\section{"Steadfast Diplomacy" and Inclusivity Under Tsai's Leadership}

As pointed out in Table 3, Taiwan under Tsai's presidency adopted a more inclusive approach towards several ASEAN members. In fact, in order to promote economic collaboration, Taipei created partnerships by integrating into NSP countries' supply chains, exported advanced medical products and services to boost Taiwan's soft power. Moreover, several Taiwanese projects were designed to construct infrastructures in NSP nations, among which the water purification plant in East Java, Indonesia (Anwar, 2020). Tsai's government worked assiduously also in terms of talent exchange. As previously mentioned, Ma Ying-jeou during the last years of his presidency had already laid the foundations for boosting Taiwan's educational image across several maritime Asian nations. Tsai implemented this strategy and made Taipei's athenaeums among the most preferred destinations for Asian students. Such a result was mostly due to the high number of scholarships available, modern facilities and the support provided by Taiwan's agencies towards the students in overcoming linguistic boundaries (Glaser, Kennedy \& Funaiole, 2018; Marston \& Bush, 2018). This approach soon started to pay dividends for Taiwan. Following Tsai's NSP implementation, ASEAN became the second-largest source of foreign students coming to Taiwan after China (Bing, 2017). Of inbound students to Taiwan from NSP countries, over half came from Malaysia, with Indonesia and Vietnam second and third, around 15.4 and $14.2 \%$ respectively. Students from non-ASEAN countries (most from India) amounted to less than 1.900 of more than 31.500 students from NSP countries (Anwar, 2020; Glaser, Kennedy \& Funaiole, 2018). While more than 31.000 foreign students were studying in Taiwan in 2017, the Tsai administration aimed to increase that figure by $20 \%$ per year, with a goal of 60.000 students from NSP countries in the next years. To this end, Taiwan's Ministry of Education announced that it would increase the numbers of scholarships offered to Malaysian and Indonesian students (Glaser, Kennedy \& Funaiole, 2018; Marston \& Bush, 2018).

Besides the better structural organization, Tsai's NSP had another distinctive feature compared with the previous "Go South" strategies sponsored by Lee and Chen. In fact, Tsai's ultimate goal was not just expanding Taiwanese financial market in other strategic areas, but also encouraging Southeast Asian businesses to invest in Taiwan. The leader of DPP aimed to pave the way for an increase of Taiwan's cultural and economic presence in Asia and, more importantly, an increase of Southeast Asia's cultural and economic presence in Taiwan (Glaser, Kennedy \& Funaiole, 2018). Essentially, a situation of "mutual increase of presence" (Bing, 2017: 121). Therefore, for the new leader in charge since May 2016, Taiwan had to become a sort of hub for Asian investments, as well as the starting point for relevant FDI directed to ASEAN and Southeast Asian nations. ASEAN, particularly, accounted for an overwhelming majority of Taiwanese exports and foreign direct investment within the NSP's framework (Marston \& Bush, 2018). Between January 2016 and April 2018, ASEAN received over $86 \%$ of Taiwan's exports (Anwar, 2020). In 2017 Taipei's exports to ASEAN totaled US \$ 58.57 billion, a 14.2 \% increase than 2016 (Anwar, 2020; Marston \& Bush, 2018). As pointed out by Marston \& Bush (2018), between 2016 and April 2018, of the top ten NSP countries as a destination for Taiwanese exports, seven were ASEAN countries.

In light to Taiwan's aim to provide strong investments into ASEAN countries, NSP has positively impacted in response. Inbound investment from those nations increased by nearly $25 \%$ in 2017 alone (Marston \& Bush 2018). Still in 2017, Singapore and Malaysia were responsible for FDI flows of US $\$ 138.32$ and $\$ 74.26$ million respectively, while India and Australia, two non ASEAN nations, provided capital to Taiwanese economy with a meager $\$ 2.57$ and $\$ 46.73$ million respectively (Glaser, Kennedy \& Funaiole, 2018). Aside from such prominent inbound investments, Taiwan experienced remarkable results also in terms of tourism. Of the 2.3 million tourists from NSP countries in 2017, 2.14 million came from the ASEAN region (Marston \& Bush, 2018). On the other hand, non-ASEAN countries accounted for a meager remainder of 147.380 travelers. The number of tourists traveling from ASEAN countries rose by $16 \%$ in 2016 and more than $29 \%$ in 2017 (Marston \& Bush, 2018). It ought to be underscored that this boost likely stemmed in part from the Tsai administration's relaxation of visa requirements on Thailand and Brunei in 2016, which grew by $57 \%$ and 52\% respectively. Moreover, tourism from the Philippines saw a 69\% jump in arrivals between 2016 and 2017 following similar visa policy changes. On this respect, Vietnamese tourist figures experienced a homogeneous trend, as they nearly doubled from 196.636 in 2016 to 383.329 in 2017 (Marston \& Bush, 2018). 


\section{The Close Bond Between Taiwan and Indonesia \\ Diplomatic and Economic Cooperation}

Beyond the impressive gains in trade and investment flows, tourism, and student exchange, Tsai's leadership has enhanced Taiwanese presence in Southeast Asia also regarding bilateral diplomatic engagement (Naz \& Rizwan, 2021: 47-50). Following her intrepid political strategy, several ASEAN countries have been seeking Taipei's support in the last years. In this regard, Indonesia, which is the largest economy and the most demographic relevant nation in Southeast Asia, has forged solid diplomatic ties with Taiwan following the inclusive policies inaugurated under Tsai's presidency. Particularly, Jakarta has expressed strong interest in Taiwan's engineering technology, especially concerning ship building techniques and the construction of water filtration systems (Herlijanto \& Paramitaningrum, 2016: 11791181). It was not a coincidence that between 2017-2018 Edy Putra Irawady, the then Indonesia's Deputy Minister for Trade and Enterprise, made multiple trips to Taiwan to learn more about the country's technical expertise in metal, electronics, and fisheries, and how such knowledge might benefit Jakarta's socioeconomic apparatus (Marston \& Bush, 2018).

Arguably, the relations between Taiwan and Indonesia have historically been quite positive. In 1989, Indonesia was among the first Southeastern Asian nations to grant Taipei's partial recognition through the opening of a government agency: the Taipei Economic and Trade Office (TETO) in the capital city (Wang \& Lu, 2008: 435-436; Herlijanto \& Paramitaningrum, 2016: 1179). As a consequence, the status of the Republic of China in the region was enhanced, in line with the "pragmatic diplomacy" sponsored by Lee Teng-hui (Bing, 2017). As claimed by Ku (2002: 238-241), Taiwan relied on the export of its significant economic resources in order to establish credible political ties with Indonesia. As a matter of fact, since TETO's inauguration Taipei kept its presence in Jakarta's financial system steady across the years. Even after the Asian financial crisis occurred in 1997-1998, Taiwan did not back down and continued to invest profusely in Indonesia (Ku, 2002: 239-240). Consequently, also due to the GSP inaugurated by both Lee's and Chen's administrations, in 2002 Taiwan became among the five largest investors in Indonesia (Herlijanto \& Paramitaningrum, 2016: 1180). For more than a decade (2002-2015), Taiwanese companies and entrepreneurs have provided extensive capitals to Jakarta's economy, with more than US \$100 million in more than 275 projects (Herlijanto \& Paramitaningrum, 2016: 1179-1180).

Taiwan's FDI has covered a variety of sectors. For instance, in 2010 Taipei has pledged to launch a project aimed at developing Morotai, an island located in the North Maluku province of Indonesia. This project was finalized to support the Southeast Asian archipelagic country to develop Morotai into a new economic hub consisting of a seafood-processing industry, tourist resort and an industrial zone (Herlijanto \& Paramitaningrum, 2016: 1180). In addition, Taiwan has sponsored technical missions in Indonesia to support local farmers increase their productivity. Such missions have been employed also concerning the fishery assistance, especially following Taipei's commitment to collaborate with Indonesian universities (Paramitaningrum, 2013; 155-159).

In response to the great support provided by Taiwan, Jakarta has offered relevant human capital. In fact, since 2011 Taiwan has become the second largest destination for thousands of Indonesian migrant workers. According to the report released by the National Body for Placement and Protection of the Indonesian Workers, more than 78.000 workers coming from Indonesia migrated in the Asian island in 2011 (Tsay, 2015: 69-71). Such numbers increased across time, as in 201482.000 Indonesians found employment in Taiwan. In 2015, the total number reached 238.300 (Tsay, 2015: 74). The majority of them was employed as housekeepers for Taiwanese families, as well as caregivers for elderly people. The profit generated in Taiwan had significant economic impacts in Indonesia, as, according to Herlijanto \& Paramitaningrum (2016: 1180-1181), foreign workers contributed significantly to the US $\$ 8.55$ billion that Jakarta had received from its overseas migrant workers in 2015. In addition, Jakarta has streamlined the bureaucratic process concerning the acceptance of Taiwanese citizens. In fact, the sign of good TaiwanIndonesia diplomatic relations might be perceivable, among others, from the Indonesian decision to allow Taipei's citizens to enter Indonesia without visa for a limited period (Herlijanto \& Paramitaningrum 2016: 1182). 


\section{Taiwanese Soft Power in Indonesia}

Despite such remarkable outcomes in terms of economic cooperation and peaceful diplomatic relations, it ought to be highlighted that Indonesia adheres to the "One China" policy. Essentially, for Jakarta the People's Republic of China is the only "official China" with Beijing as its institutional capital. However, this situation has not thwarted Taiwan to establish a solid bilateral cooperation with Jakarta in order to expand its increasing soft power in the big Asian archipelagic country (Bing, 2017: 111-113). On this point, Tsai Ing-wen's pragmatic approach has been extremely helpful. Unlike some of her predecessors, who used to insist on Taiwan's political recognition as a main goal, Tsai decided to use informal channels to boost Taipei's presence in the country. For instance, under her leadership Taiwan funded the establishment of agencies such as the TEC (Taiwan Education Center) aimed at promoting Taipei's education system in Indonesia (Herlijanto \& Paramitaningrum, 2016: 1184). The TEC was established in Surabaya, East Java, as well as the opening of the a second TETO office in this city. While the TEC has been directly founded and supported by Taiwan's Ministry of Education, another organization was established in Jakarta without a direct formal support from Taipei: the Jakarta Taiwan Education Center (JTEC). The latter was created in March 2015 and together with the Association of Taiwan Alumni in Indonesia (ICATI), has encouraged young Indonesians to study in Taiwan (Anwar, 2020; 120-121).

Taiwan's activism in promoting its education system is a clear symbol of how Taipei considers important the spread of its soft power in Indonesia (Glaser, Kennedy \& Funaiole, 2018). In addition to the aforementioned openings, Taiwan has provided a number of scholarships to specifically increase the number of Indonesians who are interested in continuing their studies in Taiwanese atheneums. As a matter of fact, besides the scholarship program generally provided to international students (named as the "Taiwan Scholarship"), Taipei has also established specific programs, in cooperation with Jakarta's official authorities, to allow more Indonesian students to pursue a higher degree in Taiwan (Tsay, 2015: 80). On this respect, in 2013 Taipei's Ministry of Education has signed a Memorandum of Understanding with the Aceh Province, located on the northern end of Sumatra, to provide 35 scholarships annually to the students originally from this area. Furthermore, Taiwan has also pledged to finance special scholarships for Indonesian students through the support of several Taiwanese universities and government institutions (Herlijanto \& Paramitaningrum, 2016: 1182).

Taiwan's soft power has been enhanced also by establishing contacts with Indonesian academics. Collaborations between Jakarta's TETO and several Indonesian academics and intellectuals occurred frequently in the last few years (Glaser, Kennedy \& Funaiole, 2018). Particularly, among the atheneums which started an official collaboration encouraged by TETO there were: Paramadina University, University of Indonesia, President University, the Habibie Center, as well as the Indonesian Institute of Science (LIPI). As a consequence, following the institution of such academic relations, several Indonesian professors have been regularly invited to participate in Taiwanese conferences and seminars (Paramitaningrum, 2013; 152154). The academic bonds were increased especially since 2012, when Taiwan's Ministry of Foreign Affairs and the Habibie Center had collaboratively organized an "Indonesia-Taiwan Dialogue" held in Taipei. As pointed out by Herlijanto \& Paramitaningrum (2016: 1186), other similar events have been organized in the following years. In 2016, for instance, the event has been expanded to include also scholars from all ASEAN countries; because of that, it changed name and became the "Taiwan-ASEAN Dialogue".

Finally, Taiwan has relied on another aspect to boost its soft power in Indonesia: popular culture. Among the exploitation of governmental agencies and the utilization of academic relations established during the last years, Taipei's popular culture has played an important role (Chen, 2002). In this regard, the appearance of Taiwanese movies and series on local television networks has increased the perception of the Asian island's image across several strata of the large Indonesian population (Didier, 2018: 239-240). The popular factor should be taken into great consideration. If the agencies operate mainly on middle class households and while the academic ties can affect only a selected elite of well-educated people, Taiwan's popular culture can potentially reach millions of Indonesians pertaining to different cultural backgrounds. Concretely, Taiwan has invested in the "popular factor" since early 1990s. Particularly, in 1994 the New Legend of Madame White Snake, a 1993 Taiwanese television series, was broadcasted with success by the SCTV (Surya Citra Televisi Indonesia), one of the private TV stations beginning to proliferate in the 
country since 1992 (Paramitaningrum, 2013; 156-158). However, it was with the Meteor Garden, a 2001 Taiwanese drama, that Taiwanese popular culture was spread with great results. Therefore, since 2001 Taipei can count also on informal channels which have impacted significantly in expanding Taiwanese habits, culture and traditions in Indonesia.

\section{DISCUSSION}

\section{Taiwanese Hydro-Diplomacy in Indonesia \\ Water Crisis in East Java}

As shown, Taiwan and Indonesia have established concrete diplomatic and economic bonds across recent years. Tsai's inclusive strategies have upgraded the already prominent role played by Taipei in the Indonesian socio-cultural apparatus. Since 2019, the collaboration between these two countries has been based also on another important matter: hydro-diplomacy. The latter has been constantly emerging related to nations that experience frequent water shortages, depletion of clean hydric resources and great rates in population growth. These three elements combined might constitute the "perfect storm" for dangerous social crises and economic downturns (Zeitoun, 2014: 181-183). In this regard, Indonesia has often been dealing with hydro related crises in recent times, especially concerning high rates of pollution in the rivers and the lack of adequate infrastructures aimed at providing clean water. In order to cement further the already strong ties with Jakarta, Taiwan has pledged to provide technological support in solving Indonesian water issues.

Taiwanese support has been mainly directed towards East Java, where the situation is particularly complicated. Drought, pollution, poor resource management, overpopulation and the negligence of local authorities in addressing water-related issues have been threatening Indonesia's most populous island with total water scarcity (Mujiono, 2020: 17-18). The latter is a serious problem not only for Java but also for the whole archipelagic Asian country. In 2019, Indonesia's Agency for Meteorology, Climatology, and Geophysics has warned that severe drought could be felt in seven of the country's provinces, with secondlevel drought in many more, including Jakarta (Walton, 2019). Particularly, some of the worst water shortages of the entire nation are felt on Java which, despite holding just $10 \%$ of the nation's water supplies, is home to more than $60 \%$ of the country's population as well as the location of many of its largest cities, and much of its agriculture (Mujiono, 2020). According to Walton (2019), Java's situation seems already compromised to a greater extent. Indonesia's Ministry of Public Works and Housing has predicted that Java's water levels will drop to 476 cubic meters per person per year by 2040 . This is categorized as "total scarcity" and is far below the current annual level of 1169 cubic meters per capita (Zeitoun, 2014: 176178). Ideally, local authorities suggest a water's amount of 1600 cubic meters per capita per year.

According to Walton (2019), the vast majority of Indonesia's water usage (70\%) goes to agriculture, with less than $10 \%$ for domestic, municipal, or industrial purposes. Most agricultural water supplies come from rainwater, while irrigation remains limited and of poor quality, and is often poorly maintained. The result is that dry seasons strike farmers particularly hard. Ironically, Indonesia as a whole has a surplus of water, but most of it is located on less populated islands such as Kalimantan and Papua. The latter, for instance, has approximately $70 \%$ of Indonesia's water supplies but just $13 \%$ of the population. However, redistributing water resources from one island to another is virtually impossible due to transportation and management reasons. Therefore, each island has to provide for its own water supply.

Java's water shortage is entirely man-made. Increased urbanization, environmental degradation and intensive agriculture have contributed to worsening an already complex situation, as well as creating difficulties in capturing and storing rainwater (Hayati, 2017: 43-45). When the latter comes, most of it becomes runoff, flowing into rivers and even causing floods, instead of being stored for future use. Furthermore, Java's rivers are heavily polluted and unsuitable for anything more than livestock and irrigation. Just four of Java's 44 large rivers meet standards known as Class 2, namely suitable for water recreation, but not for drinking, and several are laden with silt caused by erosion and agriculture (Walton, 2019; Hayati, 2017). For instance, the Ciliwung River, which flows through West Java and Jakarta, doesn't even meet Class 4 standards, meaning it is suitable only for irrigation. In addition, almost half of Jakarta's 
groundwater is contaminated by fecal matter, while $80 \%$ contains Escherichia Coli, which is the major cause of potentially fatal diarrhoeal illnesses such as typhoid (Hayati, 2017. 47-48).

In order to solve such tangled scenario a number of measures ought to be taken into consideration. Primarily, the construction of fresh water reservoirs. This might be a solution to increment Java's scarce hydro resources in the short term. As pointed out by Hayati (2017), several projects have been examined by Jakarta's officials since 2015, while in 2019 the Indonesian government planned the construction of 26 new reservoirs (Walton, 2019). In addition, biological experts have suggested new cultivation strategies. The production of rice, the country's primary staple, consumes massive amounts of water. Nevertheless, farmers around the country, even in drought-prone areas, are encouraged to increase rice production to achieve self-sufficiency. To relieve its poor water resources Indonesia ought to shift towards less waterintensive crops and livestock (Hayati, 2017: 48). For instance, as mentioned by Walton (2019), cassava and sweet potatoes' cultivation should be incentivized, since they are crops more suitable to dry regions. In this regard, a number of local initiatives have already popped up across the country aimed at urging residents to eat traditional and less intensive crops.

However, Jakarta's long term goal should be to reduce its great levels of pollution in freshwater sources, since constructing new reservoirs or shifting cultivation methods will not be enough for a country with exponential rates in growth population such as Indonesia. Particularly, as mentioned, in East Java rivers and groundwater are heavily polluted. Such a situation is a serious issue, especially due to the fact that more than $20 \%$ of the island's population uses piped water (Hayati, 2017). Consequently, local sources must be cleaned up and modernized if Java's authorities want to avoid running out of usable water, either for basic human needs either for consumption. Because of that, water purification plants are extremely useful in these circumstances, as they can provide clean and exploitable hydro resources with the existing sources, without waiting for the construction of reservoirs or the inevitable change of habits in terms of cultivation of crops.

\section{Taiwan Water Corporation (TWC): Efficiency and Reliability}

In January 2019, Taiwan and Indonesia signed an important MOU which in the coming years will alleviate East Java's water crisis and provide great support for hundreds of thousands of Indonesian families (Anwar, 2020). Taiwan Water Corporation is expected to build a new water purification facility in Malang, the second most populous city in the province. According to TWC, the construction of this infrastructure would supply local rural communities and urban areas with 35.000 tonnes of water each day. The project will not be of great expenditure, as TWC expects to invest between US $\$ 12.96$ to US $\$ 16.2$ million. However, although the size of the investment is relatively small, it would give Taiwanese water company visibility in Indonesia and help expand their reach in the local market

TWC's operation in East Java is a direct result of the hydro-diplomacy sponsored by Tsai Ing-wen. Among the inclusive strategies adopted by Taiwan's leader towards ASEAN nations, and particularly towards Indonesia, hydro-diplomacy is the most recent. Taiwanese technological know-how has been used by Tsai's administration to provide a solution to a long aged and problematic issue for millions of Indonesians: access to clean water. Following the MOU signed in January 2019 the relations between Taipei and Jakarta are expected to be even more intertwined.

It ought to be mentioned that TWC is a technological excellence in the water sector. It is a state-owned enterprise which was set up by merging 128 water treatment plants in 1974. Due to a number of reasons, in recent past water loss management had become an important issue in Taiwan. Rapid industrial development, including increased vehicle use, electrical power generation, manufacturing of food, beverages, textiles, plastic, and metal, has affected pollution levels and other environmental problems, specifically water pollution (Ming \& Hwong, 2013: 302-304). As claimed by Putri (2018: 3-4), in 1998 the Taiwan Environmental Protection Administration (EPA) reported that 16\% of the total length of Taiwan's 21 major rivers was ranked as severely polluted, while another $22 \%$ were considered lightly and moderately polluted. In addition, frequent earthquakes, and climate change had sensibly endangered this precarious situation. Hence, to a greater extent Taiwan was experiencing a similar critical water crisis compared with what is occurring nowadays in Indonesia, particularly in East Java. However, Taipei managed to solve the majority of its water issue thanks to TWC's technological efficiency. 
Since 2004, TWC has been working assiduously to reduce water losses and provide clean hydro resources. On this respect, the leakage rate (real losses) has come down from $24.58 \%$ (2004) to $15.49 \%$ (2017). According to the Water Loss Reduction Plan (2013-2022), which is a 10-year strategy aimed at further lowering water losses and upgrade Taiwanese facilities, TWC has invested US $\$ 2.65$ billion to reduce leakage rate under the $14.00 \%$ threshold. In addition, it should be taken into consideration that Taiwan's average water tariff is the $3^{\text {rd }}$ lowest in the world. Thus, besides construction, TWC aims to enhance its water management ability for increasing efficiency of water loss reduction and reducing budget expenditure. Providing high standard service and high quality drinking water has been a goal that TWC has persistently pursued in the last years. In light of the remarkable results obtained within its national boundaries, the company established in 1974 has approached foreign markets, especially in Southeast Asia. As a matter of fact, the company, after becoming a leader among domestic water utilities, hopes to keep pace with the best international water utilities. The construction of Malang's water purification facility in East Java, following the MOU signed in January 2019, will certainly increase TWC's presence in the Indonesian market.

\section{CONCLUSION}

Taiwanese activism in Southeast Asia has been pervasive since late 1980s. Several leaders have tried to enhance Taipei's visibility in the region in order to detach from mainland China's geopolitical influence. As examined in this paper, across time Taiwan has adopted numerous different strategies aimed at expanding its presence in the region. Among such strategies, hydro-diplomacy is nowadays playing a central role. There are two main reasons for that. Primarily, hydro-diplomacy in the coming future will become increasingly relevant in international relations. Many countries will likely experience water shortages and hydro related crises due to max urbanization and population's exponential growth. Particularly, Southeast Asia and Subsaharan Africa are the two areas of the world which are expected to deal with such complicated issues. In this regard, Taiwan is eager to acquire further influence by providing foreign support to all the countries in need of water resources. As occurred with the MOU for the construction of Malang's water purification plant in East Java, Taiwan has shown great interest in expanding its soft power through signing "water agreements".

Secondly, hydro-diplomacy might become a useful channel through which gaining considerable amount of foreign capitals. Taipei could find a reliable source of inbound investments by exporting its technological know-how in the water sector, especially if Taiwan exports technological excellence, such as TWC's operative knowledge. As shown, the size of TWC's investment in East Java has been relatively small: however, if the Indonesian province will experience positive effects in terms of water supply following the construction of the purification plant, the company will gain tremendous visibility. Such visibility might lay the foundations for signing new contracts not only in Indonesia or Southeast Asia but also in other parts of the world. Therefore, hydro-diplomacy might easily become a valuable tool to increase Taiwan's political and economic status.

Among the leaders who have been ruling Taiwan since late 1980s Tsai Ing-wen has been the most inclusive with Southeast Asian nations. Under her presidency Taipei has formed stronger ties with a historic regional partner such as Indonesia. The main reason for that is mostly due to her smart approach. Lee Tenghui and Chen Shui-bian, two of Tsai's predecessors, had based their foreign strategies basically on exporting Taiwanese capitals in the region. Their "Go South" policies paved the way for Taipei's economic penetration in several Southeast Asian nations. However, Lee and Chen were overwhelmingly concerned by the confrontation with mainland China and failed in opening Taiwan's economy to foreign inbound investments. On the other hand, Tsai soon realized that investing huge amounts of money in Asian economies was not enough and that a harsh confrontation with Beijing would ultimately drain Taiwan's resources without tangible results. Therefore, besides shifting from Ma Ying-jeou's flexible approach towards China to a more confrontational attitude, Tsai started to open Taiwan's financial system to inbound investments. In this way, she created the perfect environment to open up the rich and dynamic Taiwanese market to other Asian nations. Hydro-diplomacy, among the measures adopted by the leader elected in 
2016, has been the symbol of such inclusive strategy and paved the way for an increased Taiwanese presence in the region.

\section{REFERENCES}

Anwar, D.F. (2020). Indonesia and the ASEAN outlook on the Indo-Pacific. International Affairs, 96(1), 111-129.

Bing, N.C. (2017). Taiwan's Go South Policy: Déjà vu All Over Again. Contemporary Southeast Asia, 39(1), 99-126.

Chen, J. (2002). Foreign Policy of the New Taiwan: Pragmatic Diplomacy in Southeast Asia. Cheltenham (UK)-Northampton (MA, USA), Edward Elgar.

Didier, L. (2018). Economic diplomacy: The "one-China policy" effect on trade. China Economic Review, 48, 223-243.

Glaser B., Kennedy S., \& Funaiole M.P. (2018). The New Southbound Policy: Deepening Taiwan's Regional Integration. Center for Strategic \& International Studies.

Hayati, A., Tiantono, N., Mirza, M.F., Putra, I.D.S., Abdizen, M.M., Seta, A.R., Solikha, B.M., Fu'adil, M.H., Putranto, T.W.C., Affandi, M., \& Rosmanida. (2017). Water quality and fish diversity in the Brantas River, East Java, Indonesia. Journal of Biological Researches, 22(2), 42-49.

Herlijanto, J., \& Paramitaningrum. (2016). Economic Diplomacy, Soft Power, and Taiwan's Relations with Indonesia. Contemporary Chinese Political Economy and Strategic Relations: An International Journal, 2(3), 1173-1194.

Hickey D. (2006). Foreign Policy Making in Taiwan. From Principle to Pragmatism. London, Routledge. Lin, W.C. (2008). The Limits of Democratic Appeal and Economic Leverages: Relations with ASEAN Countries. In S. Tsang (Ed.), Taiwan and the International Community (pp. 189-212). Bern: Peter Lang AG International Academic Publishers.

$\mathrm{Ku}, \mathrm{C} . \mathrm{Y}$. (2002). Indonesia's relations with China and Taiwan: From politics to economics. Asian Perspective, 26(4), 227-256.

Marston, H., \& Bush, R.C. (2018). Taiwan's engagement with Southeast Asia is making progress under the New Southbound Policy. Brookings.

Ming, C.C., \& Hwong, W.M. (2013). An assessment of Taiwan's energy policy using multi-dimensional energy security indicators. Renewable and Sustainable Energy Reviews, 17, 301-311.

Mujiono, D.I.K. (2020). Opportunities of International Cooperation in Relocating the New Capital of Indonesia. Interdependence Journal of International Studies, 1(1), 13-22.

Naz, S., \& Rizwan M. (2021). Power Transition in the South China Sea Challenges for Regional Peace. Journal of Politics and Development, 11(1), 44-51.

Paramitaningrum. (2013). Enhancing People-to-People Cooperation between ASEAN and East Asia Countries through Counterparts: The Case of Indonesian Students in Taiwan. Journal of ASEAN Studies, 1(2), 148-160.

Rawnsley, G. (2012). Approaches to soft power and public diplomacy in China and Taiwan. The Journal of International Communication, 18(2), 121-135.

Putri, M.S.A., Lou, C.H., Syai' in, M., Ou, S.H., \& Wang, Y.C. (2018). Long-Term River Water Quality Trends and Pollution Source Apportionment in Taiwan. Water, 10(10), 1-17.

Tsay, C. (2015). Migration between Southeast Asia and Taiwan: Trends, characteristics and implications. Journal of ASEAN Studies, 3(2), 68-92.

Walton, K. (2019) In Java, the water is running out. The Interpreter.

Wang, H., \& Lu, Y.C. (2008). The conception of soft power and its policy implications: A comparative study of China and Taiwan. Journal of Contemporary China, 17(56), 425-447.

Zeitoun, M., Warner, J., Mirumachi, N., Matthews, N., McLaughlin, K., Woodhouse, M., . . Allan, T.J.A. (2014), Transboundary water justice: A combined reading of literature on critical transboundary water interaction and 'justice', for analysis and diplomacy. Water Policy, 16(1), 174-193. 